\title{
Infiltration Rates and Sediment Production Following Herbicide/Fire Brush Treatments
}

ROBERT W. KNIGHT, W.H. BLACKBURN, AND C.J. SCIFRES

\begin{abstract}
Terminal infiltration rates were similar in soils on which a heavy whitebrush (A loysia lycioides) cover had been aerially treated with $2 \mathrm{~kg} /$ ha (active ingredient) of $20 \%$ tebuthiuron pellets 4 years previously or on tebuthiuron-treated plots which had been prescribed burned the winter about 9 months prior to infiltration measurements, compared to untreated sites. However, sediment production was greater from plots treated with the herbicide than from areas subjected to the herbicide-fire system or from untreated plots. Only minor variations in infiltration rates occurred among sites originally dominated by running mesquite (Prosopis reptans) which were aerially sprayed with $2,4,5-T+$ picloram (1:1) at 1.1 $\mathrm{kg} / \mathrm{ha} 3.5$ years previously, burned 10 months previously, subjected to the herbicide-fire system or left untreated. However, sediment production on the running mesquite areas which had been sprayed tended to be greater than on untreated plots. Sediment production on areas subjected to the herbicide-prescribed burning system tended to be less than from brush-covered plots. Differences in sediment production in both experiments were generally attributed to slightly reduced mulch loads and mulch covers where the brush was removed as a leaf mulch donor by herbicide treatment. Prescribed burning apparently compensated for loss of brush leaf mulch by promoting grass cover on herbicide-treated areas.
\end{abstract}

The effective integration of herbicides and prescribed burning into brush management systems for south Texas has been demonstrated for improvement of Macartney rose (Rosa bracteata)infested rangeland (Scifres 1975, 1978, 1980; Gordon et al. 1981). Such systems also appear promising for improvement of rangeland supporting excessive cover of species such as running mesquite and whitebrush (Scifres 1981). However, the potential effects of such integrated brush management systems on soil hydrologic properties have not been studied.

Hughes (1966) reported that infiltration rates of Tillman clay loam averaged $5.6 \mathrm{~cm} / \mathrm{hr}$ at approximately 2 years after aerial spraying of honey mesquite (Prosopis glandulosa var. glandulosa) with 2,4,5-T [(2,4,5-trichlorophenoxy)acetic acid] compared to 3.7 $\mathrm{cm} / \mathrm{hr}$ on adjacent untreated rangeland on the Rolling Plains of Texas. Although average soil water contents in the surface $30 \mathrm{~cm}$ were normally higher on sprayed than unsprayed areas, soil-water contents were highest under the honey mesquite canopies, regardless of treatment:

Hendricks and Johnson (1944) reported that burning of steep mountain slopes decreased infiltration rates by the destruction of the protective vegetal and mulch covers. Where burns are of adequate intensity to significantly reduce organic matter content of soil, aggregate stability may decline (Wahlenburg et al. 1939). Range burning has been reported to intensify the water repellency

\footnotetext{
Authors are assistant professor and professors, Department of Range Science, Texas A\&M University, College Station, 77843. Published with the approval of the Director, Texas Agricultural Experiment Station as TA 16804. The efforts of Julia Scifres in manuscript typing and of J.L. Mutz in retrieving hydrologic data are appreciated. The authors are grateful to P.H. Welder and Dick Horton for furnishing land for the research.

Manuscript received April 24, 1981.
}

of certain soils (Adams et al. 1970, Debano and Karammes 1966, Buckhouse and Gifford 1976).

Because of the differential behavior of fire as influenced by variations in weather, fuel characteristics and composition of plant stands, the influence of burning on hydrologic properties of soils may vary considerably within and among plant communities. For example, infiltration rates were decreased and sediment production was increased following removal of the protective cover by burning of coppice dune a reas within a pinyon-juniper community (Roundy et al. 1978). Conversely, burning had no effect on these properties in dune interspace areas. Soil bulk density and organic matter contents were unaffected by burning, regardless of area burned.

Ueckert et al. (1978) reported that burning had little effect on rainfall infiltration of honey mesquite-tobosagrass (Hilaria mutica) dominated sites in north Texas, and had little influence on sediment load in runoff from slopes of less than $1 \%$. Most of the soil physical properties that affect infiltration on the clay soils were not altered significantly by burning. In general, it appears that water infiltration rates are either unaffected (Buckhouse and Gifford 1976, Ueckert et al. 1978) or are decreased slightly (Roundy et al. 1978, McMurphy and Anderson 1965) following range burning. However, the slightly decreased infiltration rates generally exceeded expected rainfall rates for the respective areas.

Within a given soil texture class and set of surface characteristics, degree of slope strongly influences sediment losses following burning. Wright et al. (1976) reported that erosion losses, runoff and water quality were unaffected following bulldozing and burning to remove junipers (Juniperus spp.) from level terrain with limestone-derived soils in central Texas. However, water quality was decreased and erosion increased for 9 to 15 months where the slopes were 15 to $29 \%$ and for 15 to 30 months when the slopes were 45 to $53 \%$. Rates of erosion loss stabilized within 18 months on all slopes after herbaceous foliar cover reached 63 to $68 \%$.

The objective of his research was to compare terminal infiltration rates and sediment production of 2 range sites which had been subjected to herbicide-prescribed burning systems in South Texas.

\section{Study Area and Treatments}

A whitebrush-dominated site near Tilden, Texaș, and a running mesquite dominated site between Freer and Cotulla, Texas, were selccted for study. The site near Tilden supported a heavy cover of whitebrush with scattered honey mesquite, spiny hackberry(Celtis pallida), blackbrush acacia (Acacia rigidula), and lotebush (Ziziphus obtusifolia). The soil of the site is predominantly Clareville sandy loam (fine montmorillonitic, hyperthermic family of Pachic Argiustolls).

Tebuthiuron [N-(5-[1,1-dimethylethyl]-1,3,4-thiadiazol-2-yl)$N, N^{\prime}$-dimethylurea] pellets $(20 \%)$ were aerially applied at $2 \mathrm{~kg} / \mathrm{ha}$ (active ingredient) to the whitebrush site on November 20, 1975. Herbicide was applied to duplicate, 2.1-ha areas alternated with untreated strips of the same size. On January 24, 1979, half of each plot was burned with a headfire when the air temperature was 
$13^{\circ} \mathrm{C}$, the relative humidity was $19 \%$ and the wind speed was 3 to 8 $\mathrm{km} / \mathrm{hr}$ from the southeast. Plots treated with tebuthiuron supported $1,750 \mathrm{~kg} /$ ha of standing fine fuel (material $\leq 0.3 \mathrm{~cm}$ ) which burned uniformly and completely. However, the untreated plots did not burn because of the marginal fine fuel load $(940 \mathrm{~kg} / \mathrm{ha})$ which was not uniformly distributed.

The running mesquite-dominated soil was Maverick clay loam (fine montmorillonitic, hyperthermic family of Ustollic Cambothids). The site was aerially sprayed with $1.1 \mathrm{~kg} / \mathrm{ha}$ of $2,4,5-$ $\mathrm{T}+$ picloram (4-amine ${ }^{\circ}-3,5,6$-trichloropicolinic acid) (1:1) in 47 liters/ha of a diesel oil:water (1:4) emulsion on May 25, 1977. Grazing exclosures, 1 ha in size, were erected on the sprayed and on an adjacent unsprayed area the following December. On January 25,1979 , half of each exclosure was burned with a headfire when the air temperature was $24^{\circ} \mathrm{C}$, relative humidity was 52 to $58 \%$ and wind speed was 10 to $13 \mathrm{~km} / \mathrm{hr}$ from the southeast. Fine fuel load $(1,940 \mathrm{~kg} / \mathrm{ha})$ was uniformly distributed on the herbicide-treated area so that $90 \%$ of the surface area of the plot was covered by the fire. The unsprayed plot supported only $380 \mathrm{~kg} /$ ha of fine fuel which occurred primarily in the interspaces between brush plants. Consequently, only about $40 \%$ of the area was covered by the burn.

\section{Material and Methods}

On September 1979 near Tilden, whitebrush canopy cover reductions was estimated in a belt, $3.7 \mathrm{~m}$ wide, on a diagonal across each plot. Basal diameters of stumps of burned-down whitebrush were measured in $25,1-\mathrm{m}^{2}$ quadrats, equidistantly spaced on a diagonal across each plot.

The whitebrush-dominated site was fenced to exclude grazing for the first year following herbicide application. Thereafter, it was grazed with cows and calves in the spring (April) and fall (September) to remove 50 to $60 \%$ of the standing crop of the key management species.

The exclosures on the running mesquite-dominated site were grazed in the spring and fall as described for the whitebrushdominated sitc. Canopy reduction of woody plants on each plot was visually estimated in mid-September 1979.

Infiltration rates were determined with a drip-type rainfall simulator (Blackburn et al. 1974) on $10,0.4-\mathrm{m}^{2}$, randomly-located runoff plots in each treatment at both locations during midOctober 1979. Within treatment variation (variation among subplots) was allocated to the residual for testing differences $(P \leq .05)$ among treatments. The runoff plots were prewet with a sprinkler system to remove antecedent soil-water content differences. The simulated rainfall rate, $20.3 \mathrm{~cm} / \mathrm{hr}$ for $0.5 \mathrm{hr}$, was chosen to ensure runoff from all treatments. The amount of runoff was determined at 5-minute intervals. Upon termination of the simulated rainfall applications, runoff collections from each plot were thoroughly agitated and a 1-liter subsample removed. The sediment was filtered from each subsample, dried at $105^{\circ} \mathrm{C}$ for $24 \mathrm{hr}$, weighed and converted to sediment yield ( $\mathrm{kg} / \mathrm{ha}$ ) as an index of sheet erosion.

Foliar cover of grasses and forbs, and percentage ground cover by mulch and rock $>0.5 \mathrm{~cm}$ diam.) were estimated for each plot using a $1 \mathrm{~m}^{2}$ frame with $10-\mathrm{cm}$ grids. Grass, forbs, and standing dead herbage were clipped at ground level, dried for $48 \mathrm{hr}$ at $60^{\circ} \mathrm{C}$, and weighed

Bulk density of soil sampled at 0 to 3 and 5 to $8 \mathrm{~cm}$ deep immediately adjacent to each runoff plot was determined by the core method (Black 1965). Also, a soil sample from 0 to $8 \mathrm{~cm}$ deep and immediately adjacent to each runoff plot was used for determination of soil texture by the hydrometer method (Bouyoucos 1962), organic matter by the Walkley-Black method (Walkley and Black 1934) and aggregate stability by the wet-sieve method (Kemper and Koch 1965).

\section{Results and Discussion}

Since the study areas represented different soils and vegetation, the comparisons among treatments are restricted to those within study sites.

\section{Whitebrush-Dominated Site}

At the time the evaluation of hydrologic properties was initiated, the tebuthiuron application had killed $96 \%$ of the whitebrush-a typical response based on past research (Scif res et al. 1979). However, many of the original stems were standing at the time of evaluation of hydrologic properties on plots receiving only the herbicide. In contrast, the prescribed burn consumed standing dead whitebrush stems $1.5 \mathrm{~cm}$ in diameter or smaller lending a more open aspect to areas subjected to the tebuthiuron-burning system. Grasses, especially multiflowered false-rhodesgrass Chloris pluriflora) but including species such as longspike silver bluestem (Bothriochloa saccharoides) and vine mesquite (Panicum obtusum), dominated the plots treated with tebuthiuron and burned.

There was little difference among plots in the bulk density of soils from the surface $8 \mathrm{~cm}$ (Table 1). Organic matter content of soils from plots treated with herbicide-prescribed burning was significantly lower than on untreated plots, apparently the result of standing crop removal by the fire. Organic matter content of soils from tebuthiuron-treated plots was only slightly less than that from untreated plots, presumably a result of reduced leaf mulch

Table 1. Soll chemical and physical properties in mid-October 1979 of whitebrush-dominated and running-mesquite dominated sites after implementation of herbicide-prescribed burning systems in south Texas.

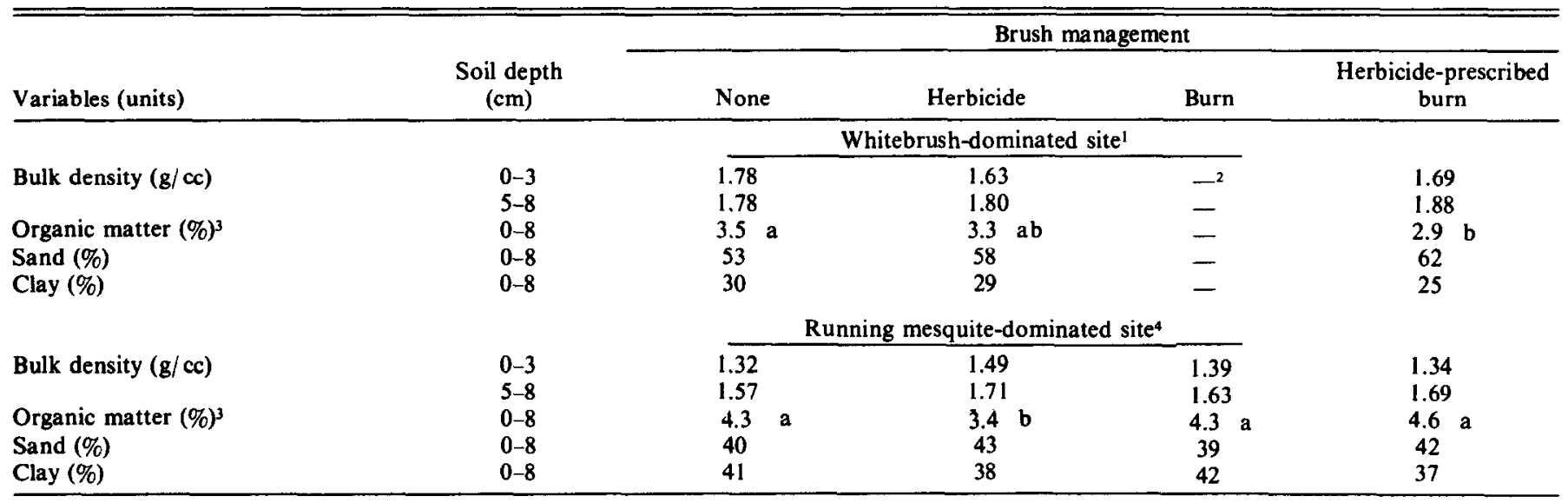

ITreated with $2 \mathrm{~kg}$ / ha of tebuthiuron on November 20, 1975, and burned on January 24, 1979.

'Untreated plots did not burn on this site.

${ }^{3}$ Means followed by the same letter are not significantly different $(P \leq .05)$ according to Duncan's multiple range test.

-Treated with $1.1 \mathrm{~kg} /$ ha of 2,4,5-T + picloram spray on May 24, 1977, and burned on January $25,1979$. 
Table 1. Vegetation attributes and hydrologic variables in mid-October 1979 after implementation of herbicide-prescribed burning systems on a site dominated by whitebrush in South Texas.

\begin{tabular}{|c|c|c|c|}
\hline \multirow[b]{2}{*}{ Variables (units) } & \multicolumn{3}{|c|}{ Brush management ${ }^{1,2}$} \\
\hline & None & Herbicide & $\begin{array}{l}\text { Herbicide- } \\
\text { prescribed } \\
\text { burn }\end{array}$ \\
\hline \multicolumn{4}{|c|}{ Hydrologic properties } \\
\hline $\begin{array}{l}\text { Terminal infiltration rate }(\mathrm{cm} / \mathrm{hr}) \\
\text { Sediment production }(\mathrm{kg} / \mathrm{ha}) \\
\text { Aggregate stability }(\%)\end{array}$ & $\begin{array}{l}12.4 \mathrm{a} \\
730 \mathrm{~b} \\
14.8 \mathrm{a}\end{array}$ & $\begin{array}{r}15.0 \mathrm{a} \\
1925 \mathrm{a} \\
14.0 \mathrm{a}\end{array}$ & $\begin{array}{r}14.2 \mathrm{a} \\
615 \mathrm{~b} \\
21.3 \mathrm{a}\end{array}$ \\
\hline \multicolumn{4}{|c|}{ Vegetation attributes } \\
\hline $\begin{array}{l}\text { Grass standing crop }(\mathrm{kg} / \mathrm{ha}) \\
\text { Grass cover }(\%) \\
\text { Mulch load }(\mathrm{kg} / \mathrm{ha}) \\
\text { Mulch cover }(\%) \\
\text { Bare ground }(\%)\end{array}$ & $\begin{array}{r}640 \mathrm{c} \\
16 \mathrm{~b} \\
2135 \mathrm{a} \\
61 \mathrm{a} \\
19 \mathrm{~b}\end{array}$ & $\begin{array}{r}1825 \mathrm{~b} \\
25 \mathrm{~b} \\
2060 \mathrm{a} \\
29 \mathrm{~b} \\
38 \mathrm{a}\end{array}$ & $\begin{array}{r}3820 \mathrm{a} \\
63 \mathrm{a} \\
1620 \mathrm{a} \\
21 \mathrm{~b} \\
16 \mathrm{~b}\end{array}$ \\
\hline
\end{tabular}

Tebuthiuron applied on November 20, 1975, and prescribed burns installed on January 24, 1979.

2Means within a variable (row) followed by the same letter are not significantly different $(P \leq .05)$ according to Duncan's multiple range test.

following control of the brush. Differences in mulch loads at the time of the infiltration evaluations support the conclusion (Table 2). The mulch load on treated plots, especially those treated with tebuthiuron and then burned tended to be less than on untreated plots. Percentage of the soil surface covered by mulch was significantly reduced on treated plots, compared to brush-covered plots.

Terminal infiltration rates were only slightly higher on areas subjected to the brush management treatments than on untreated plots (Table 2). There was no difference in sediment production from plots subjected to the herbicide-prescribed burning system and the untreated plots. Since there was no difference in percentage of bare soil between the areas, the potential influence of decreased mulch cover on the areas treated with tebuthiuron and then burned was apparently compensated by increased grass cover. Significantly higher sediment production on plots treated with tebuthiuron, compared to those treated with the herbicide-prescribed burning system or left untreated, was attributed to a higher percentage of bare ground on the herbicide-treated plots compared to other treatments.

\section{Running Mesquite-Dominated Site}

At the time hydrologic properties were evaluated, brush canopy cover reductions averaged $78 \%, 9 \%$, and $88 \%$ on areas treated with herbicides, prescribed burning, and the herbicide-prescribed fire system, respectively. Primary grasses on the sprayed and sprayed- burned areas were multiflowered false-rhodesgrass, pink pappusgrass (Pappophorum bicolor), common curly-mesquite (Hilaria belangeri), white tridens (Tridens albescens), plains bristlegrass (Setaria macrostachya). Untreated areas or those burned only were typified by buffalograss (Buchloe dactyloides), red grama (Bouteloua trifida), whorled dropseed (Sporobolus pyramidatus), hooded windmillgrass, (Chloris cucullata), and three-awns (Aristida ssp.).

Bulk density and percentage clay or sand varied little among treatments on the running mesquite-dominated site (Table 1). There was no apparent explanation from the reduced organic matter content of soils from herbicide-treated plots compared to that from other treatments.

Terminal infiltration rates did not differ among treatments (Table 3). However, sediment production tended to be greater on plots aerially sprayed and less on plots sprayed and then burned, compared to untreated areas. Grass standing crop was greater on herbicide-treated plots than on untreated areas. However, there was a trend toward decreased mulch cover and mulch load, and increased percentage of bare ground on plots sprayed only, compared to untreated plots. The slight increase in sediment production $(380 \mathrm{~kg} / \mathrm{ha})$ from the sprayed plots was attributed to the reduced presence of mulch and the increased percentage of bare ground.

Sediment production tended to be reduced on plots which were burned only or which received the herbicide-prescribed burning system compared to undisturbed running mesquite stands (Table 3). Since the prescribed burn was ineffective in reducing the brush cover, variation in mulch cover, and percentage bare ground were minor. However, the application of prescribed burning following herbicide application increased grass standing crop slightly, compared to application of the herbicide only, and significantly increased grass standing crop compa red to untreated plots or those burned only. The herbicide treatment had a slightly higher sediment production than the prescribed burn treatment, but not significantly. This was probably due to this treatment having a higher bulk density and lower organic matter. Moreover, percentage grass on plots receiving the brush management system was greater than on plots receiving single treatments or left untreated. Apparently, increased cover of herbaceous vegetation compensated for the reduced mulch cover and the slight increase in the percentage of bare ground on sediment production.

\section{Conclusions}

Although the brush management treatments did not influence terminal infiltration rates of soil in either experiment, sediment production increased following application of herbicide to the

Table 3. Vegetation attributes and hydrologic variables in mid-October 1979 after implementation of a herbicide-prescribed burning system on a site dominated by running mesquite in South Texas.

\begin{tabular}{|c|c|c|c|c|}
\hline \multirow[b]{2}{*}{ Variables (units) } & \multicolumn{4}{|c|}{ Brush management,2 } \\
\hline & None & Herbicide & Prescribed burn & $\begin{array}{r}\text { Herbicide-prescribed } \\
\text { burn }\end{array}$ \\
\hline & \multicolumn{3}{|c|}{ Hydrologic properties } & \\
\hline $\begin{array}{l}\text { Terminal infiltration rate }(\mathrm{cm} / \mathrm{hr}) \\
\text { Sediment production }(\mathrm{kg} / \mathrm{ha}) \\
\text { Aggregate stability }(\%)\end{array}$ & $\begin{array}{c}12.8 \mathrm{a} \\
1955 \mathrm{a} \\
11.6 \mathrm{a}\end{array}$ & $\begin{array}{r}12.2 \mathrm{a} \\
2335 \mathrm{a} \\
16.2 \mathrm{a}\end{array}$ & $\begin{array}{r}12.8 \mathrm{a} \\
1300 \mathrm{a} \\
16.0 \mathrm{a}\end{array}$ & $\begin{array}{r}11.3 \mathrm{a} \\
1160 \mathrm{a} \\
12.8 \mathrm{a}\end{array}$ \\
\hline $\begin{array}{l}\text { Grass standing crop (kg/ha) } \\
\text { Grass cover (\%) } \\
\text { Mulch load (kg/ha) } \\
\text { Mulch cover }(\%) \\
\text { Bare ground }(\%)\end{array}$ & $\begin{array}{r}565 \mathrm{~b} \\
21 \mathrm{~b} \\
5435 \mathrm{a} \\
64 \mathrm{a} \\
11 \mathrm{a}\end{array}$ & $\begin{array}{r}\text { ation attrib } \\
2060 \mathrm{a} \\
30 \mathrm{~b} \\
3260 \mathrm{a} \\
51 \mathrm{a} \\
15 \mathrm{a}\end{array}$ & $\begin{array}{r}370 \mathrm{~b} \\
18 \mathrm{~b} \\
2955 \mathrm{a} \\
56 \mathrm{a} \\
12 \mathrm{a}\end{array}$ & $\begin{array}{r}2590 \mathrm{a} \\
47 \mathrm{a} \\
750 \mathrm{~b} \\
33 \mathrm{~b} \\
19 \mathrm{a}\end{array}$ \\
\hline
\end{tabular}

'2,4,S-T + picloram aerially applied on May 25, 1977 and prescribed burns installed on January $24,1979$.

${ }_{2}$ Means within a variable followed by the same letter are not significantly different ( $\left.P \leq .05\right)$ according to Duncan's multiple range test. 
whitebrush-dominated site where prescribed burning was not applied as a subsequent treatment in the management system. The same trend occurred where a running mesquite-dominated site was sprayed and not subsequently burned. In both cases, increased sediment production was attributed to reduced mulch covers, a trend toward reduced mulch loads, and increases in percentage bare ground where the herbicides were applied. Reduced mulch loads and covers were attributed to greatly decreased presence of woody plants which contribute large amounts of mulch.

Although prescribed burning of herbicide-treated areas further reduced mulch load and mulch cover compared to herbicide treatment alone, grass cover was promoted on both sites subjected to the herbicide-prescribed burning system. Grass cover on plots treated with herbicide-fire system was increased two or four-fold, compared to untreated areas, and by 2.5 times, compared to areas treated with herbicide only. Increased grass cover appa rently compensated for the potential influences reduced mulch load and cover on sediment production.

\section{Literature Cited}

Adams, S., B.R. Strain, and M.S. Adams. 1970. Water repellent soils, fire and annual plant cover in a desert shrub community of southeastern California. Ecology 51:696-700.

Black, C.A. (ed.). 1965. Methods of soil analysis. Amer. Soc. of Agron. Series No. 9. Madison, Wis.

Blackburn, W.H., R.O. Meeuwig, and C.M. Skau. 1974. A mobile infiltrometer for use on rangeland. J. Range Manage. 27:322-323.

Bouyoucos, G.J. 1962. Hydrometer method improved for making particle size analysis of soil. Agron. J. 54:464-465.

Buckhouse, J.C., and G.F. Gifford. 1976. Grazing and debris burning on pinyon-juniper sites-some chemical water quality implications. J. Range Manage. 29:299-301.

DeBano, L.F., and J.S. Krammes. 1966. Water repellent soils and their relation to wildlife temperatures. Bull. Int. Ass. Sci. Hydrol. 11:14-18.

Gordon, R.A., C.J. Seifres, and J.L. Mutz. 1981. Integration of burning and picloram pellets for Maccartney rose control. J. Range Manage. $35: 427-430$.
Hendricks, B.A., and J.M. Johnson. 1944. Effect of fire on steep mountain slopes in central Arizona. J. Forestry 42:568-571.

Hughes, E.E. 1966. Effects of root plowing and aerial spraying on microclimate, soil conditions and vegetation of a mesquite area. Texas Agr. Exp. Sta. Misc. Pub. 812.

Kemper, W.D., and E.J. Koch. 1965. Aggregate stability of soils from the western portion of the U.S. and Canada. USDA Tech. Bull. 1355.

McMurphy, W.E., and K.L. Anderson. 1965. Burning Flint Hill range. J. Range Manage. 18:265-269.

Roundy, B.A., W.H. Blackburn, and R.E. Eckert, Jr. 1978. Influence of prescribed burning on infiltration and sediment production in the pinyon-juniper woodland, Nevada. J. Range Manage. 31:250-253.

Scifres, C.J. 1975. Systems for improving Macartney rose-infested rangeland. Texas Agr. Exp. Sta. Misc. Pub. 1225.

Scifres, C.J. 1978. Range vegetation management with herbicides and alternative methods: An overview and perspective. Proc. Symp., Use of Herbicides in Forestry, USDA and U.S. Environ. Prot. Agency, Arlington, 151-165.

Scifres, C.J., J.L. Mutz, and W.T. Hamilton. 1979. Control of mixed brush with tebuthiuron. J. Range Manage. 32:155-158.

Scifres, C.J. 1980. Brush management, principles and practices for Texas and the southwest. Texas A\&M Univ. Press.

Scifres, C.J. 1981. Integrated brush management systems (IBMS) for rangeland: Concepts and application. Ann. Internat. Stockmen's School 18:74-79.

Ueckert, D.N., T.L. Whigham, and B.M. Spears. 1978. Effect of burning on infiltration, sediment, and other soil properties in a mesquite-tobosagrass community. J. Range Manage. 31:420-425.

Wahlenburg, W.G., S.W. Green, and H.R. Reed. 1939. Effect of fire and cattle grazing on longleaf pine land as studied at McNeill, Mississippi. USDA Tech. Bull. 683.

Walkley, A. and A.I. Black. 1934. An examination of the Deqtjareff method for determining soil organic matter and a proposed modification of the chromic acid titration method. Soil Sci. 37:29-38.

Wright, H.A., F.M. Churchill, and W.C. Stevens. 1976. Effect of prescribed burning on sediment, water yield, and water quality from dozed juniper lands in Central Texas. J. Range Manage. 29:294-298.

\section{RANGE \\ POSITION ANNOUNCEMENT}

Texas Tech University is seeking a Range Research Scientist for the Department of Range and Wildlife Management, one of eight academic divisions in the College of Agricultural Sciences. This is a 12-month teaching and research position with summer salary dependent upon teaching and research grants.

This 12-month appointment will be supported in part by USAID Small Ruminant Collaborative Research Support Program, the Noxious Brush and Weed Control Program, and Resident Instruction. Research responsibilities will include international travel to Peru, administration, graduate student advisement, data analysis and publication writing. The applicant also will be expected to write proposals for external funding and develop his/her own research program. Teaching responsibilities will include "Ecology and Conservation of Natural Resources" (sophomore level) and the development of a course in "Range Animal Nutrition" (Graduate level).

A Ph.D. in Range Science or in a closely related discipline is required. Position available September 1, 1983. Applications accepted until July 15, 1983, or until position is filled. Salary is to be commensurate with education and experience.

Submit a resume and the names of three references to:

Dr. Henry A. Wright, Chairperson
Texas Tech University
P.O. Box 4169
Lubbock, Texas 79409

ASSISTANT/ASSOCIATE PROFESSOR OF WILDLIFEMANAGEMENT. Two faculty positions, tenure trace academic year (9-month) appointment: $60 \%$ teaching, $40 \%$ research. Opportunities for summer research. Must have one degree in wildlife biology/management, and Ph.D. or near completion. Must be capable of field research and instruction, and effective in oral and written communication in English. Wildlife Management-Mammals: Need education and training in mammal management. Wildlife Habitat Management: Demonstrated substantive knowledge in wildlife habitat management, forestry, and vegetation manipulation. Appointment: About Sept. 15, 1983, pending anticipated funding. Closing Date: Postmarked by June 1, 1983. Application: Send transcripts, resume, reprints, letter of application, and names of three persons as references to: Wildlife Search Committee, School of Forestry, University of Montana, Missoula, MT 59812. Write or call (406) 2435521 for information. EEO/AA employer. 